\title{
Variety selection in intensive alfalfa cutting management
}

\author{
Dragan Milić* · Snežana Katanski · Branko Milošević · Dalibor Živanov
}

Institute of Field and Vegetable Crops, Maksima Gorkog 30, Novi Sad, Serbia

\begin{abstract}
Summary: Alfalfa is an autotetraploid, perennial forage crop adapted to different environments and management systems. Trial with 12 alfalfa populations was established in spring of 2014. The research involved 9 commercial alfalfa varieties from IFVCNS, Serbia, and included 3 experimental populations in the final phase of breeding program. The main objectives of this paper were to examine the impact of variety selection on alfalfa yield and plant height in intensive cutting management in order to define harvesting strategies (using 6 and 5 cuts per season), with main goal to maximize profit on alfalfa farms in Serbia and Southeast Europe. Our study clearly demonstrates that there is genetic potential in some Serbian varieties (NS Sila, Nera, NS Jelena, and Banat VS) for use in intensive cutting systems with 6 cuts per year that can meet farmers' needs in conventional or organic type of alfalfa hay production. This research represents an initial guideline for the alfalfa variety selection in intensive cutting management systems in Serbia and Southeast Europe.

Key words: alfalfa, breeding, cutting regime, persistence, yield
\end{abstract}

\section{Introduction}

Alfalfa (Medicago sativa L.) is main forage species, spread on more than 30 million hectares all around world, on almost all continents (Bouton, 2012). Nowadays, it is one of the most grown forage legume for hay, silage or pasture production and reasons for that are high nutritive value and wide adaptability (Li \& Brummer, 2012). It is a polymorphic, xenogamous and autotetraploid species characterized by extremely high genetic variability, so alfalfa varieties/populations exibit broad genetic variation (Veronesi et al., 2010). The presence of large genetic variability in alfalfa leads to creation of various range of varieties adapted to specific environments and management systems (Pembleton et al., 2010).

In order to make selection in alfalfa more efficient, breeders should carefully design and establish breeding programs, which will lead to maximization of expected

Corresponding author:

dragan.milic@ifvcns.ns.ac.rs

Acknowledgement:

This research has been funded by the Serbian Ministry of Education, Science and Technological Development within the project TR 31024

Cite this article:

Milić D., Katanski S., Milošević B., Živanov D. (2019). Variety selection in intensive alfalfa cutting management. Ratar. Povrt., 56 (1), 20-25. gains within capabilities and goals of the programs ( $\mathrm{Li} \&$ Brummer 2012; Milić et al., 2016). Breeding programs in the USA related to intensive cutting regimes are based on selection of semi or non-dormant germplasms (Putnam et al., 2005). The harvest in earlier stages of development (full budding) provides higher level of forage quality and alfalfa digestibility, but also leads to poorer yield performance. Market requirements for higher quality fodder, with higher nutritional value, lead to understanding changes in the timing of alfalfa cutting. With cutting of alfalfa in later maturity stages of development (full flowering) nutritional value decreases, while the dry matter content and yield rise. Hovewer, a less intensive cutting regime could contribute to the longer life of alfalfa stands and reduced harvesting costs (Lloveras et al., 1998; Lamb et al., 2007). Choice of the most appropriate cutting schedule for each variety it is of great importance (Kallenbach et al., 2002; Orloff \& Putnam, 2010; Rimi et al., 2014). Time of cutting is the most powerful tool under the alfalfa grower's control to affect yield and quality and fundamentally increase economic production potential; more than the variety selection, fertilization and other management factors (Orloff \& Putnam, 2006). Therefore, the selection of variety (its dormancy rating) should be considered in compliance with harvest regime choice in order to improve the yield performance and persistence of alfalfa 
in environments with temperate climates (Rimi et al., 2014). The cutting regime, or more precisely how frequently the alfalfa is cut, has a greater influence on forage quality than any other factor under the farmer's control (Putnam et al., 2005; Putnam, 2010). Analysis of the yield-quality tradeoff of alfalfa is fundamental to selecting the optimum variety as well as the optimum cutting schedule (Putnam et al., 2004). The large number of varieties, the varied soils and climate conditions even within Serbia, and the range of different types of alfalfa production (organic, conventional, with or without irrigation) make variety selection a bit of a challenge.

Objectives in this study were to: a) evaluate the influence of genetics background (variety) on alfalfa yield using intensive cutting schedule, b) evaluate the effects of intensive cutting management strategy based on maturity stages through different environmental conditions on alfalfa dry matter yield and plant height, and c) examine persistence of alfalfa varieties used in research.

\section{Materials and Methods}

Field study was conducted during 2014-2017 at the Institute of Field and Vegetable Crops in Novi Sad, Serbia, to examine interaction between intensive cutting schedule and variety.

\section{Plant material and experimental design}

Trial with 12 alfalfa populations was established in spring of 2014. The research involved 9 commercial alfalfa varieties from Serbia: Banat VS, NS Banat ZMS II, NS Mediana ZMS V, NS Alfa, Nera, NS Diva, NS Jelena, NS Sila and NS Tara created in Institute of Field and Vegetable Crops, Novi Sad, which originated from different breeding cycles and applied methods. In the trial 3 experimental populations in final phase of breeding program were included: Biomass 08/09, 1506/06 and SRB 08/09 (Table 1).

Alfalfa varieties and experimental populations were planted into a conventionally prepared seedbed at a depth of $1 \mathrm{~cm}$. The basic plot area was $6 \mathrm{~m}^{2}(1 \mathrm{~m} \times 6 \mathrm{~m})$ with row spacing of $20 \mathrm{~cm}$, in 4 replications. In the establishment year (2014), all standard cultivation practices were applied (weed and insects control). The following traits were analyzed: dry matter yield $\left(\mathrm{t} \mathrm{ha} \mathrm{h}^{-1}\right)$ and plant
Table 1. List of registered alfalfa cultivars and experimental populations used in trial.

\begin{tabular}{ll}
\hline Population & Year of release \\
\hline NS Banat ZMS II & $1964 / 2007^{*}$ \\
NS Mediana ZMS V & $1980 / 2012^{*}$ \\
Banat VS & $2005 / 2017^{*}$ \\
NS Alfa & $2005 / 2017^{*}$ \\
Nera & 2007 \\
NS Diva & 2012 \\
NS Jelena & 2014 \\
NS Sila & 2017 \\
NS Tara & 2017 \\
Biomass 08/09 & EP \\
15 06/06 & EP \\
SRB 08/09 & EP \\
*Year of additional release; EP - experimental population
\end{tabular}

height $(\mathrm{cm})$ at the moment of cutting. Green forage yield was determined by cutting the plot area and the fresh weight was determined immediately. Subsamples of approximately $200 \mathrm{~g}$ were taken from the every plot and dried in oven at $60^{\circ} \mathrm{C}$ for $72 \mathrm{~h}$ to determine forage $\mathrm{DM}$, which was used to calculate DM yield. Plots were cut three times without data recording in order to be insured successful experiment establishment. Plants were harvested at the moment of late budding or at stage of beginning of flowering (1-5\% of flowering plants per plot) - morphological stages of development according to Kalu \& Fick (1983) 4-5, during 2015-2017. Populations and varieties were evaluated through 17 cuts in total: in 2015 and 2016 - 6 cuts and in 2017 - 5 cuts, i.e. in the second, third and fourth year of plants life (Table 2).

Values for every trait were summarized as it as average performance of every genotype during 20152017 for the traits. The two-factorial analysis of variance was used for yield and plant height analysis. Year (environment) was treated as factor $\mathrm{A}$ and population as factor B. The LSD test was used to test the significance of differences.

Table 2. Harvest plot dates during 2015-2017

\begin{tabular}{lllllll}
\hline Year & 2015 & & 2016 & 2017 \\
\hline Cut & Date & $\begin{array}{l}\text { Interval between } \\
\text { cuts* (days) }\end{array}$ & Date & $\begin{array}{l}\text { Interval* } \\
\text { (days) }\end{array}$ & Date & $\begin{array}{l}\text { Interval* } \\
\text { (days) }\end{array}$ \\
\hline I & 29 April & 38 & 27 April & 36 & 09 May & 47 \\
II & 01 June & 32 & 06 June & 38 & 12 June & 34 \\
III & 30 June & 29 & 01 July & 25 & 12 July & 30 \\
IV & 27 July & 26 & 29 July & 28 & 23 August & 42 \\
V & 02 Sept. & 36 & 31 August & 31 & 20 October & 58 \\
VI & 30 October & 57 & 01 November & 61 & $\dagger$ & $\dagger$ \\
\hline
\end{tabular}

† Plots not harvested. 


\section{Results and Discussion}

Generally, environmental effects (year) and genetic background (variety) had a strong influence on yield and plant height, that did their interaction (Table 3). Overall analyses clearly demonstrate that there were significant differences among varieties for total yield and plant height during trial 2015-2017 (Table 3).

Table 3. Total dry matter yield and plant height mean squares from the ANOVA over 2015-2017, across 12 populations and 17 cuts

\begin{tabular}{llll}
\hline & & \multicolumn{2}{c}{ Mean squares } \\
\cline { 3 - 4 } Source & df & DMY & $\begin{array}{l}\text { Plant } \\
\text { height }\end{array}$ \\
\hline Year Y & 2 & $151.36^{* *}$ & $684.57^{* *}$ \\
Population P & 11 & $9.51^{* *}$ & $26.71^{* *}$ \\
Y(G) x P & 22 & 1.15 & 2.34 \\
Error & 70 & 1.68 & 3.03 \\
CV & & 7.6 & 2.7 \\
\hline
\end{tabular}

${ }^{* *}$ Significant at the 0.01 level.

The obtained results clearly demonstrate importance of genetic background on applied intensive harvesting management. Also, environmental effects significantly affected variety performance in this study. Overall report across seasons of 2015-2017 show that the highest yields were recorded with varieties NS Sila (18.4 $\left.\mathrm{t} \mathrm{ha}^{-1}\right)$, Nera (18.2 $\left.\mathrm{t} \mathrm{ha}^{-1}\right)$, Banat VS (17.9 $\left.\mathrm{t} \mathrm{ha}^{-1}\right)$ and NS Jelena $\left(17.7 \mathrm{t} \mathrm{ha}^{-1}\right)$, in intensive cutting regime, when alfalfa plants were harvested in late budding phase or at the early flowering stage according to Kalu \& Fick (1983). This common set of varieties exhibits the tallest plants in the trial with exemptions of NS Jelena and NS Sila (Table 5). The populations mean value for dry matter yield and plant height was generally similar to that of the SRB 08/09 (for yield) and to the NS Banat
ZMS II (plant height) (Tables 4 and 5). A previous analysis of relationships among agronomic traits in alfalfa clearly shows existence of low to moderate positive correlations between yield and height in alfalfa (Riday \& Brummer, 2005; Robins et al., 2007). Our findings are in compliance with previous ones because the most yielding populations (NS Sila and Nera), where not the tallest varieties in the trial (NS Mediana ZMS V and Banat VS). However, there are strong correlations on molecular level between flowering date and plant height in alfalfa (Herrmann et al., 2010; Li \& Brummer, 2012). We can confirm these findings because the earliest varieties were among the tallest ones (Banat VS) in our study.

In the second and third year of stand life (2015 and 2016), the highest yields were recorded in varieties NS Sila and Banat VS. These 2 populations (along with Nera and NS Jelena), should be recommended for organic alfalfa production in Serbia when it is needed to use alfalfa for 3 years in intensive cutting schedule (Karagić et al., 2016). In the last year of trial performance (2017), or the fourth year of plant life, populations were cut 5 times. There are slight changes in variety rankings in 2017. These rang modifications are related to the alfalfa persistence in intensive cutting regime. The highest level of persistence was found in variety Nera $\left(16.3 \mathrm{t} \mathrm{ha}^{-1}\right)$, followed by SRB 08/09, NS Mediana ZMS V and NS Sila for dry matter yield production. The lowest yields and plant highest were recorded in varieties NS Diva, NS Alfa and NS Tara, even their yield performance was not to low (around 15 $\left.\mathrm{t} \mathrm{ha}{ }^{-1}\right)$. These findings leads to conclusions that these alfalfa varieties are not suitable for intensive cutting regime in Serbia and Southeast Europe, and more than that this group of populations should be endorsed and proposed to the growers in hilly and mountain regions were alfalfa is harvested less than five times (more dormant varieties).

Table 4. Total dry matter yield ( $\left.\mathrm{t} \mathrm{ha}^{-1}\right)$ of followed alfalfa varieties/ populations during 2015-2017.

\begin{tabular}{lcccc}
\hline Population & 2015 & 2016 & 2017 & $\begin{array}{l}\text { Mean } \\
2015-2017\end{array}$ \\
\hline NS Banat ZMS II & 18.3 & 17.0 & 13.9 & 16.4 \\
Banat VS & 20.0 & 18.8 & 15.0 & 17.9 \\
Biomass 08/09 & 17.4 & 18.0 & 14.6 & 16.7 \\
NS Tara & 18.0 & 16.7 & 13.6 & $18.4^{*}$ \\
NS Sila & $21.1^{* *}$ & 18.8 & 15.5 & 17.7 \\
NS Jelena & 19.2 & 18.5 & 15.3 & 17.5 \\
NS Mediana ZMS V & 18.0 & 19.1 & 15.5 & $18.2^{*}$ \\
Nera & 19.4 & 18.8 & 16.3 & 15.5 \\
NS Alfa & 16.9 & 16.3 & 12.7 & 16.6 \\
NS Diva & 17.4 & 16.7 & 12.5 & 17.3 \\
15 06/06 & 17.6 & 17.3 & 15.0 & 1.2 \\
SRB 08/09 & 18.2 & 18.2 & 15.6 & 1.6 \\
Mean & 18.5 & 17.8 & 14.6 & \\
\hline LSD 0.05 & & & \\
$\quad 0.01$ & & & & \\
CV\% & 2.1 & & & \\
\hline
\end{tabular}

\footnotetext{
${ }^{*}$ Significant at the 0.05 level and ${ }^{* *}$ Significant at the 0.01 level respectively.
} 
Table 5. Average plant height (cm) of followed alfalfa varieties/ populations during 2015-2017

\begin{tabular}{|c|c|c|c|c|}
\hline Population & 2015 & 2016 & 2017 & Mean \\
\hline NS Banat ZMS II & 63.7 & 66.3 & 71.0 & 64.6 \\
\hline Banat VS & 60.7 & 63.9 & 69.2 & 67.0 \\
\hline Biomass 08/09 & 60.3 & 65.6 & 69.1 & 65.0 \\
\hline NS Tara & 58.7 & 62.5 & 64.3 & 61.8 \\
\hline NS Sila & 60.0 & 63.6 & 68.1 & 63.9 \\
\hline NS Jelena & 59.6 & 65.7 & 70.1 & 65.1 \\
\hline NS Mediana ZMS V & 62.4 & 67.1 & 71.5 & 67.0 \\
\hline Nera & 61.0 & 65.2 & 71.3 & 65.8 \\
\hline NS Alfa & 58.2 & 62.1 & 66.1 & 62.1 \\
\hline NS Diva & 58.9 & 62.8 & 66.7 & 62.8 \\
\hline $1506 / 06$ & 58.9 & 63.8 & 68.1 & 63.6 \\
\hline SRB 08/09 & 59.8 & 65.2 & 71.3 & 65.4 \\
\hline Mean & 60.2 & 64.5 & 68.9 & 64.5 \\
\hline LSD 0.05 & 2.8 & & & 1.6 \\
\hline 0.01 & 3.8 & & & 2.2 \\
\hline $\mathrm{CV} \%$ & 2.7 & & & \\
\hline
\end{tabular}

Because of high demands from market for applications of intensive cutting regimes the most persistence alfalfa varieties from this research, should be recommended for growing in conventional farming systems or especially in organic production of alfalfa in Serbia (Karagić et al., 2016).

In this paper nutritive value of alfalfa populations was not studied, but reality of alfalfa production is that yield and quality are negatively correlated (Kallenbach et al., 2002; Brink et al., 2010 Milić et al., 2014; Karagić et al., 2016). Harvesting alfalfa at early maturity growth stages (i.e. pre-bud or early-bud) leads to higher forage nutritive values with significant decreased of green forage and dry matter yields. We can assume that alfalfa dry matter yields obtained in this study are of highest quality regarding crude protein, NDF, ADF and ADL content (Table 6). According to Putnam (2010), alfalfa harvested in late budding or very early flowering is considered as a premium to good quality hay. This hay classes are characterized with high relative feed value, which means high digestibility. Many papers reported that harvesting alfalfa in 6 cutting regime increase hay quality values more than 7 $\%$ (Kallenbach et al., 2002; Brink et al., 2010). However, comparing 4 and 5 cutting regimes Milić et al. (2014), reported differences in hay quality parameters up to five percentages in favor of 5 cuts regime. Harvesting management systems, or more precisely the maturity of the alfalfa in the time of harvest, determine forage quality and yield (Orloff \& Putnam, 2010). Alfalfa yield is particularly influenced by the selection of variety (Kallenbach et al., 2002, Lamb et al., 2006, Li \& Brummer, 2012), but nutritive value (quality) of alfalfa hay is strongly affected by the cutting system (maturity stage), and weed control.

In alfalfa production in Serbia, exploitation of cutting schedule with five cuts per year is the most efficient cutting management which does allow full exploitation of cultivar genetic potential together with favorable environmental conditions in most of Serbian regions. For this approach the most suitable varieties are: Banat VS, Nijagara, NS Banat ZMS II, NS Mediana ZMS V, Nera and NS Jelena (Milić et al., 2014; Karagić et al., 2016).

This research presents a preliminary guide for more intensive cutting management and alfalfa variety selection choices in Serbia and Southeast Europe. However, this study does not resolve fully all rising questions. While extremely short cutting schedules are widely known to produce superior quality hay, they

Table 6. Phenological stages and description of different quality categories of alfalfa hay (Putnam, 2010)

\begin{tabular}{|c|c|c|c|c|}
\hline Phenological stage hay category & $\mathrm{CP}(\%)$ & $\mathrm{ADF}(\%)$ & NDF $(\%)$ & $\mathrm{RFV}$ \\
\hline $\begin{array}{l}\text { Very early maturity -pre bloom } \\
\text { Supreme }\end{array}$ & $>22$ & $<27$ & $<34$ & $>180$ \\
\hline $\begin{array}{l}\text { Early maturity - pre bloom } \\
\text { Premium }\end{array}$ & $20-22$ & $27-29$ & $34-36$ & $150-180$ \\
\hline $\begin{array}{l}\text { Beginig of flowering } \\
\text { Good }\end{array}$ & $18-20$ & $29-32$ & $36-40$ & $125-150$ \\
\hline $\begin{array}{l}\text { Full flowering } \\
\text { Fair }\end{array}$ & $16-18$ & $32-35$ & $40-44$ & $100-125$ \\
\hline $\begin{array}{l}\text { Mature seed pods } \\
\text { Utility }\end{array}$ & $<16$ & $>35$ & $>44$ & $<100$ \\
\hline
\end{tabular}


also usually result in reduced stand life (Putnam, 2010). In this study yields were severely reduced after 4 years in some alfalfa populations of production using intensive 6 cuts harvesting regime (NS Diva $12.5 \mathrm{t} \mathrm{ha}^{-1}$ and NS Alfa $12.7 \mathrm{t} \mathrm{ha}^{-1}$ respectively). Frequent harvests reduce the ability of alfalfa plant to replenish root carbohydrate and protein reserves, causing death of plants, or weaker plants that are more susceptible to disease (Putnam, 2004). Also, intensive cutting regimes increase production costs, which are already higher with more harvests per year. However, there are alfalfa varieties with adequate response to the intensive cutting regime that can meet demands of local and regional markets (NS Sila, Nera, NS Jelena, Banat VS).

\section{Conclusions}

Cutting schedule is the main factor in determination of yield and quality in alfalfa. Intensive cutting schedule should be adapted to the most desirable type of alfalfa variety even in small country like Serbia.

Use of intensive cutting system with 6 cuts per year in Serbia is absolutely possible and realistic, but adjustments have to be made according to: a) type of alfalfa production - for hay or haylage, b) variety selection (dormancy group of selected variety); c) conventional or organic production type; d) appropriate harvesting equipment; e) environmental effects (plain or mountain region and climate type), and f) stand longevity - persistence, of chosen alfalfa variety.

Some of the followed varieties (NS Diva, NS Alfa and NS Tara) are not suitable for intensive 6 cut harvesting management. This group of populations is of great interest, for uses in less intensive cutting regimes with 4 cuts per year (areas with some limitations for alfalfa farming, such as light acid, heavy hydromorphic soils in hilly and mountainous regions).

Our study clearly demonstrates that there is genetic potential in certain Serbian varieties (NS Sila, Nera, NS Jelena and Banat VS) for use in intensive cutting systems with 6 cuts per year and can meet farmers' needs in conventional or organic type of alfalfa hay production.

Therefore, application of good management practices, followed by genetic improvements and favorable environmental conditions could contribute to the improvement of alfalfa productivity and to the yield quality trade of in alfalfa production, both in Serbia and Southeast Europe.

\section{References}

Bouton, J. (2012): Breeding lucerne for persistence. Crop \& Pasture Science, 63: 95-106.

Brink, G., Hall, M., Shewmaker,. G., Undersander, D., Martin, N., \& Walgenbach, R. (2010): Changes in alfalfa yield and nutritive value within individual harvest periods. Agronomy Journal, 102(4): 1274-1282.
Herrmann, D., Barre, P., Santoni, S., \& Julier, B. (2010): Association of a CONSTANS-LIKE gene to flowering and height in autotetraploid alfalfa. Theoretical and Applied genetics, 121: 865876.

Kallenbach, R.L., Nelson, C.J., and Coutts, J.H. (2002): Yield, quality, and persistence of grazing- and hay-type alfalfa under three harvest frequencies. Agronomy Journal, 94:1094-1103.

Kalu, B.A. \& Fick, G.W. (1983): Morphological Stage of Development as a Predictor of Alfalfa Herbage Quality. Crop Science, 23(6): 1167 -1172 .

Karagić, Đ., Vasiljević S., Mihailović V., Milić D., Mikić, A., Milošević B., Katanski, S., Živanov, D., \& Dolapčev, A. (2016): Production of crude feed (in Serbian). Proceedings of the $50^{\text {th }}$ Seminar of Agronomists of Serbia, Zlatibor, 24-30 January 2016. Institute of Field and Vegetable Crops, Novi Sad, 22-40.

Lamb, J.F.S., Jung H.J.G., Sheaffer C.C., \& Samac, D.A. (2007): Alfalfa leaf protein and stem cell wall polysaccharide yields under hay and biomass management systems. Crop Science, 47:1407-1415.

Li, X., \& Brummer, E.C. (2012): Applied Genetics and Genomics in Alfalfa Breeding. Agronomy, 2: 40-61.

Lloveras, J., Ferran, J. Alvarez A., \& Torres, L. (1998): Harvest management effects on alfalfa (Medicago sativa L.) production and quality in Mediterranean areas. Grass and Forage Science, 53: 88-92.

Milić, D., Katić, S., Katanski, S., Dugalić, G., Bokan, N. \& Vasiljević, S. (2014): Effect of Genotype and Effect of Genotype and Applied Management on Alfalfa Yield and Quality. Ratar Povrt., 51(2): 91-99.

Milić D., Katanski S., Karagić, Đ., Milošević, B., Vasiljević, S., TaškiAjduković, K. \& Nagl N. (2016): Towards intrapopulation improvement of alfalfa yield and persistence. Ratar Pourt, 53(1): 20-23.

Orloff, S., \& Putnam, D.H. (2010): Adjusting alfalfa cutting schedules for economic conditions. Proceedings of the 2010 California Alfalfa \& Forage and Corn/Cereal Silage Mini-Symposium. November 30 - 2 December, Visalia, CA, USA. http:// alfalfa.ucdavis.edu/+symposium/2010/

Pembleton, K.G., Donaghy, D.J., Volenec, J.J., Smith, R.S., \& Rawnsley, R.P. (2010): Yield, yield components and shoot morphology of four contrasting lucerne (Medicago sativa) varieties grown in 3 cool temperate environments. Crop and Pasture Science, 61: 503-511.

Putnam, D.H., Orloff, S.B., \& Teuber, L.R. (2004): Economic Sustainability: Genetic and cutting schedule influences on yield quality trade-off. Proceedings of $4^{\text {th }}$ International Crop Science Congress, Brisbane, Australia, 26 September- 1 October 2004.

Putnam, D.H., Orloff, S.B., \& Teuber, L.R. (2005): Strategies for balancing quality and yield in alfalfa using cutting schedules and varieties. p.237-252. In Proc. 35th California Alfalfa and Forage Symp., Visalia, CA. 12-14 Dec. 2005.

Putnam, D.H. (2010): Changing forage quality testing for alfalfa hay markets: Proceedings of the 2010 California Alfalfa \& Forage and Corn/Cereal Silage Mini-Symposium. November $30-2$ December, Visalia, CA, USA.

Riday, H., \& Brummer, E.C. (2005): Relationships among biomass yield components within and between suspecies of alfalfa Medicago Genetic Reports. Vol. 4. Available at http:// www.medicago-reports.org/

Rimi, F., Macolino, S., Leinauer, B., Lauriault, L.M., \& Ziliotto, U. (2014): Fall dormancy and harvest stage impact on alfalfa persistence in a subtropical climate. Agronomy Journal, 106 (4):1258-1266.

Robins, G.J., Bauchan, R.G., \& Brummer, E.C. (2007): Genetic Mapping Forage Yield, Plant Height, and Regrowth at Multiple Harvests in Tetraploid Alfalfa (Medicago sativa L.). Crop Science, 47:11-18.

Veronesi, F., Brummer, E.C., \& Huyghe, C. (2010): Alfalfa. In: B Boller, UK Posselt, F Veronesi (Eds.), Fodder Crops and Amenity Grasses. Series: Handbook of Plant Breeding, Springer, New York, USA, 5: 395 - 437 


\section{Značaj izbora sorte u intenzivnoj proizvodnji lucerke}

\section{Dragan Milić · Snežana Katanski · Branko Milošević · Dalibor Živanov}

Sažetak: Lucerka (Medicago sativa L.) je najznačajnija višegodišnja krmna biljka visokih prinosa krme, sena, senaže, odlične hranljive vrednosti. Sistem kosidbe predstavlja odlučujući faktor u determinaciji prinosa i kvaliteta lucerke. U cilju provere reakcije populacija lucerke stvorenih u Institutu za ratarstvo i povrtarstvo na intenzivan sistem kosidbe (sa primenjenih 6 otkosa u II i III godini života i 5 otkosa u IV godini trajanja useva) postavljen je ogled u Novom Sadu u 2014. godini, a rezultati su praćeni tokom 2015-2017. godine. U ispitivanje je uključeno 9 priznatih sorti i 3 eksperimentalne populacije lucerke stvorene u različitom vremenskom periodu, primenom različitih metoda oplemenjivanja i germplazme različitog porekla. Dobijeni rezultati pokazuju da režim kosidbe lucerke treba prilagoditi tipu/grupi sorti, načinu proizvodnje i rejonu gajenja. Najveći prinosi suve materije tokom perioda ispitivanja registrovani su kod sorti NS Sila (18,4 t/ha), Nera (18,2 t/ha), Banat VS (17,9 t/ha) i NS Jelena $(17,7 \mathrm{t} / \mathrm{ha}) \mathrm{u}$ intenzivnom sistemu kosidbe. Režim kosidbe sa 6 otkosa u Srbiji predstavlja realan način proizvodnje, ali prilagođavanje ovom sistemu kosidbe zavisi od cilja proizvodnje, sorte, rejona gajenja, starosti useva. Genetički potencijal NS sorti lucerke koji odgovara maksimalnom intenzitetu kosidbe sa 6 otkosa u godini ostvaren je sa sortama NS Sila, Nera, Banat VS i NS Jelena, a za sistem kosidbe sa 5 otkosa u godinama pune eksploatacije, a koji najviše odgovara farmerima u umereno-kontinentalnom klimatu Srbije, mogu se preporučiti i sorte NS Banat ZMS II, NS Mediana ZSM V. Ostvareni rezultati predstavljaju značajan doprinos razumevanju značaja primene intezivnog sistema kosidbe tokom godina iskorišćavanja a posebno kritičnoj fazi vezanoj za izbor sorte i različite rejone gajenja, načine iskorišćavanja, kao i potrebe različitih tržišta za senom lucerke.

Ključne reči: oplemenjivanje, lucerka, prinos, sistem kosidbe, trajnost 